\title{
WHAT BORGES LEARNED FROM WHITMAN: The Open Road and Its Forking Paths
}

JOSEPH J. BENEVENTO

THE EXTENT AND IMPORTANCE of Walt Whitman's influence on Latin American poetry is well documented. José Santos Chocano, Ruben Darío, Jose Martí, Pedro Mir, Octavio Paz, and the Nobel laureate Pablo Neruda are just some of the Latin American poets who owe an obvious debt to Whitman and his poetry. ${ }^{1}$ Even the Argentinian poet and short story writer, Jorge Luis Borges, acknowledges the influence of Whitman on his early poetry; in fact Borges admits that he once thought of Whitman as "poetry itself."2 Indeed, Whitman has been a consistent hero for Borges, who has written essays about Whitman and even translated and published selections from Leaves of Grass. $^{3}$

However, several factors clearly separate Borges's affinity for Whitman from that of most other Latin American poets. First of all, there is little of the style or subject matter of Whitman's work apparent in Borges's poetry. Neruda's Residencia en la tierra and his Canto General are particularly Whitmanic in their voice and structure and in their call for universal brotherhood. Mir's "Contracanto a Walt Whitman" is, in part, an attempt to extend Whitman's transcendental brand of democracy into a call for freedom and equality for all oppressed peoples. In Santos Chocano's boast that "Walt Whitman has the North and I have the South," we can see the clear attempt to imitate Whitman's larger-than-life, bardic pose. The fact is that usually when people talk about a poet who bears a resemblance to or owes a debt to Whitman, they most often associate this influence in terms of ostensible style or characteristic subject matter. Some poets are deemed Whitmanic for their rough-hewn, "natural" style, as with Sandburg; others for their "barbaric yawp," as with Ginsberg. Still others are judged to be Whitman's "disciples" because they deal with typically Whitmanic themes, such as human equality and universal brotherhood, the breaking down of sexual or religious taboos, or the divinity of the commonplace. Such judgments seem particuarly apt when the poets in question combine their treatment of these themes with a larger-than-life voice and style, which thereby qualifies them to speak for all of us, as is sometimes the case in the poetry of Neruda or Paz.

And so it is especially curious that Borges's poetry holds very little in common with any of the poetry of the other Whitman "disciples." Borges almost never utilizes a bardic voice or tone, rarely has been colloquial or explicit in his style or subject matter, and has most often opted to avoid the use of free verse. Borges, if he has been influenced by Whitman, does not seem to have 
been influenced in the same way or even by the same Whitman that influenced most of his fellow poets.

Anyone who reads Borges's essays on Whitman comes to recognize what it was that Borges admired in Whitman fairly readily because Borges has reaffirmed the source of his admiration again and again. ${ }^{4}$ Borges clearly establishes a distinction between "Whitman" the character of "Song of Myself" and other early poems, who represents the larger-than-life poetic hero, and Whitman the writer and man, who was to Borges a brilliant and innovative literary theorist. Borges has explained more than once that what Whitman did in "Song of Myself" and some of the other poems in Leaves of Grass was to create a composite hero, "Walt Whitman," based in part on an idealized version of himself, but also meant to include all men and women, or all readers, potentially. Whitman thus was able to form an epic hero fit for democracy, an individual being who encompassed all individuals. The persona and character, "Walt Whitman," Borges explains, is not only Walt Whitman, but each of his readers as well. Hence Whitman has found a way to make the reader a character and an active participant in the work of art, which is, in fact, incomplete without him. There is a "trinity" therefore of the writer, reader and the unifying, composite persona. Each one of us can find ourselves in "Walt Whitman," and Whitman frequently called upon his readers to do exactly that.

In yet another discussion of the essential Whitman that serves as a foreword to Homage to Walt Whitman, Borges argues that few so-called followers of Whitman have really captured his essence: "Strange to say, Whitman has many imitators - and no disciples. People think that they are Walt Whitman if they are sufficiently breezy, slangy and unmetrical. The plan of making a character out of the writer and the reader has not been attempted again."5 Clearly Borges believes that the real essence of the Whitman disciple would be in the duplication of the experiment of the trinity and the attention paid to giving the reader direct access into the work of art. In fact, Borges once predicted that if someone would attempt to repeat Whitman's experiment the results could be "maybe as good, but quite different." 6 With this Borgesian emphasis on the difference in ostensible form and style and even subject matter in mind, one begins to realize that Borges's own most important work, his fiction, might be more aligned to what he perceived to be the basis of Whitman's literary message and contribution than most of the so-called Whitmanic poetry, of his contemporaries. Indeed, fiction would be an ideal genre to take up an experiment largely focused on a composite persona and an active, participating reader.

Borges was not the first nor the only person to note the importance that Whitman attached to the notion of an active reader. A number of Whitman's contemporaries, ${ }^{7}$ some modern critics, ${ }^{8}$ and of course Whitman himself, ${ }^{9}$ frequently have pointed out how Whitman's poetry was meant to invite and challenge response and participation from its readers. However, Borges may 
have been one of the few writers who decided to adapt the literary theories he discovered in Whitman to his own fictional practices.

Most Whitman critics would agree that in some important ways Whitman's first few editions of Leaves of Grass were meant as practical, actual answers to the theoretical call for a poet that Emerson had set forth in "The Poet" and other essays. Whitman, himself, however, also extended that call for a new breed of poets, and he also sought a new breed of readers who would be worthy and equal to such poets, so that literature and life both could be more fully democratic endeavors. In Democratic Vistas, and in a number of other contexts, Whitman's search for the writers and readers willing to cooperate in the new joint venture of the work of art is apparent. Borges, as a true disciple, has attempted throughout much of his fiction to allow for direct reader participation in his work, frequently through the use of a composite persona. However, just as Borges has claimed that Whitman's trinity experiment has gone largely unnoticed because of its degree of success, so too has Borges's adaptation of that trinity theory gone largely unrecognized because of its subtlety and high degree of success; Borges's attempt has in some ways been "maybe as good but quite different." Borges has been at least as concerned as Whitman was in attracting and challenging what Julio Cortázar, in his novel Rayuela (Hopskotch), would later refer to as the "accomplice reader." An examination of several of Borges's key stories in comparison to some of Whitman's most clearly related poems will demonstrate just how Borges was able to adapt and modify Whitman's ideas in his own inspired and innovative fiction.

"Salut Au Monde!," too often discounted by critics as a mere geography book catalogue of places and people that Whitman felt impelled to list, is instead, as Borges has argued in "Nota sobre Walt Whitman," an innovative poem, important to Whitman's poetic theory. The poem begins: "O take my hand Walt Whitman! / Such gliding wonders! such sights and sounds!"10 Since Walt Whitman is being addressed, one has to wonder who the speaker is. Clearly, one possible answer is that the reader has become the questioner, has attained direct participation in the poem by being able to address Whitman directly. However, what may be happening can be far more than a rhetorical trick if we consider the possibility that the poet or man Walt Whitman is joining here with all of his readers to ask questions of the composite figure "Walt Whitman," the only one who is capable of the tremendous vision and unity achieved in the poem.

"Salut Au Monde!" is certainly a poem about the universal brotherhood of all peoples and about the transcendent poetic vision that can see that equality in spite of the apparent diversity. For that very reason, the use of the composite persona is especially apt; "Salut Au Monde!" is about transcending all limitations by joining ourselves with the writer who thereby is buoyed by identity and relation and can thus express with us the message of the poemuniversal relation and brotherhood. "What do you see Walt Whitman?" (1. 41) 
and "What do you hear Walt Whitman?" (1. 22) are questions by Whitman and by the readers; two members of the trinity converge to cause the tremendous vista of the third. It is not merely Walt Whitman the man who haughtily claims connection with the universe because he can list many of the people and places of that universe. It is Whitman and his companion readers joined together and thus limitlessly able to see relation and connection. Hence, by the disarmingly simple device of allowing us to ask questions of the character "Walt Whitman," Whitman has allowed us a direct way into the process and signification of the poem.

In "El Zahir" Borges - ostensibly the historic man, and the narrator and main character of the story - is jolted by the death of Teodolina Villar, a very specifically Argentine celebrity, and his concern for her seems almost idiosyncratic. However, a twenty cent piece that he receives for change the night of the funeral becomes for him an obsessive focus of concern, the Zahir, an unforgettable object which eventually causes him to be in danger of losing all specific sense of self. Hence this coin transforms him from Borges into "Borges" the composite figure because through a focus on the particular he gains insight into the unity of all things, though without a full loss of self: "I am not he who I was before, but still I am allowed to recall and perhaps even relate what has happened. I am still, even partially, Borges." 11 This early passage from "El Zahir" is essentially a definition of what taking on the composite persona entails. It implies a surrender of self (yet not a total surrender) in order to take on the others, to make the imaginative leap bevond the specific. In his own way, Borges is asking us to "take my hand," so that together we can achieve the heightened awareness and insight possible in the work of art.

Of course Borges is not as certain as Whitman is in "Salut Au Monde!" that this alliance will have happy results. At the end of his story he is unsure whether the obsessed focusing on the Zahir, the one object that has come to imply the universe, will lead to madness or a vision of God. The Zahir, then, is perhaps a symbol for the individual work of art, in which the author attempts to merge with his audience without a total surrender on either side, and with neither party ever sure of what the end result will be. In both Whitman's and Borges's cases, however, these respective works are clear examples of the formulation of the composite personal, made up of the writer and any of his readers willing to go fully on the joint venture, the adventure of the work of art.

This notion of both life and art as a shared venture comes through even more clearly in the ruling metaphors of Whitman's "Song of the Open Road" and Borges's "The Garden of Forking Paths." In "Song of the Open Road" as in "Salut Au Monde!" Whitman seeks fellow travelers. "Allons! whoever you are come travel with me! / Traveling with me you find what never tires" (11. 114-115). Whitman claims that on this journey with him we will find "realization," "adhesiveness," and the "efflux of the soul" $(11.85,91,105)$. Whitman is 
sharing a life philosophy based on encounter, but he is simultaneously inviting us on the aesthetic adventure of the work of art.

Just as Borges was unsure of the final result of his venture in "El Zahir," Whitman warns us that easy resolution is not possible: "Listen! I will be honest with you, / I do not offer the old smooth prizes, but offer rough new prizes. ..." (11. 140-141). He is inviting us to a new way of looking at art as a shared risk-taking by writer and reader. Whitman, however, does very much hope that we will have the courage to join him in both his poetry and in his life philosophy. He ends the poem with a virtual plea for companions: "Will you give me yourself? will you come travel with me? / Shall we stick by each other as long as we live?" (11. 223-224). Whitman needs us in order to make his venture meaningful; he needs us to share his view of the "universe itself as a road, as many roads, as roads for traveling souls" (1. 180). At the core of Whitman's poetic theory is the notion of the creative work as a shared endeavor; this endeavor is incomplete, therefore, without the reader's active participation.

There exists a fundamental relation between this view of both life and art as an open road and the notion that Borges presents of a "garden of forking paths." The forking paths suggest both the infinite possibilities of life and the many different ways that any one work of art can be interpreted. The added fork in Borges's notion is that more than one interpretation can be valid for the same reader. One of Whitman's fondest wishes was to get his readers so caught up in his "atmosphere" that they would then feel both willing and able to pursue their "own flights." In "The Garden of Forking Paths" this pursuit is inevitable and unending if we as active readers understand and accept the major premises of the story.

The central metaphor of the story is a book written by a Chinese philosopher, Ts'ui Pên, which is simultaneously a novel and a labyrinth. In this work all things are possible, all events may come to pass. Stephen Albert, the sinologist who has uncovered the long puzzling secret of the book that is a labyrinth, explains: "in all fictions when one man is faced with alternatives he chooses one at the expense of the others. In the almost unfathomable Ts'ui Pên he chooses simultaneously all of them. He thus creates various futures, various times that start others, which in their turn will branch out and bifurcate in other times."12

As in Whitman's poetry, the mere innovations of the literary metaphor of the garden of forking paths are not enough of themselves; Albert goes on to explain that the book is a symbol for life and its infinite possibilities; it particularly encourages a new view of time and process. Like Whitman's open road, Borges's forking paths comprise a transcendent vision and an aesthetic vision at once; only if the readers get fully involved in the latter will they fully appreciate or understand the former. If the readers are not equal to the task of the poem or story, how can they be equal to the vision inherent in either one? In both cases we see a theory of life as process and a connection to art as the 
self-same process, one of infinite possibility and collaboration. Both works call for a commitment from the reader, the fellow traveler, and much of the meaning and merit of the creative endeavor is left for the reader to realize.

"Song of Myself," in addition to being Whitman's longest poem, is certainly the poem in which Whitman most fully presents the concept of the companion reader. The composite persona is also clearly in view. The very first lines of the poem establish the "I" as a composite: "I celebrate myself, and sing myself, / And what I assume you shall assume, / For every atom belonging to me as good belongs to you." (11. 1-3). Some have denied Whitman the right to "assume" for all of his readers; however, perhaps he really only does so for the active, participating reader who willingly joins him on the journey that is the poem.

Whitman goes on to ask a question that has probably made more than one conventional reader uneasy, "Have you practis'd so long to learn to read? / Have you felt so proud to get at the meaning of poems?" These lines may indicate that the old way of interpreting literature is no longer valid or sufficient; literature should not have an author-based, fixed meaning for us to "get." Instead Whitman advises us to:

\footnotetext{
Stop this day and night with me and you shall possess the origin of all poems,

You shall possess the good of the earth and sun, (there are millions of suns left,)

You shall no longer take things at second or third hand, nor look through the eyes of the dead, nor feed on the spectres in books,

You shall not look through my eyes either, nor take things from me,

You shall listen to all sides and filter them from your self. (11. 33-37)
}

The reader in some sense is the "origin of all poems"; there is no literature without a reader to respond to it. Yet what Whitman is proposing is more than a truism because he suggests a method of reading that is primary and participatory, hence no longer a second or third hand endeavor. All that we read we filter through ourselves, thereby recreating it. Hence Whitman's poem is in part about how to read his poem; he has placed the hints in his book and it is up to us to make the discoveries for ourselves first-hand. Once again the vision of the poem-its message of democracy, equality and of transcending the commonplace through recognition of the divinity of all things and the sublime nature of the self-cannot be really meaningful to the reader unless the reader feels equal to the message. Unless the reader can appreciate and live the message first-hand it will mean "nothing, or next to nothing" (1. 356). Everyone is invited to the poem, to the meal "equally set" (1. 372) where no one is turned away, but not all will accept the invitation. Not everyone is willing to meet Walt Whitman halfway and become with him the "Walt Whitman" who is the composite hero of the poem.

As in "Song of the Open Road," Whitman ends "Song of Myself" with a 
plea and with a promise to wait for us when we are ready to participate in the shared venture: "Listener up there! what have you to confide to me? ... (Talk honestly, no one else hears you, and I stay only a minute longer.)... Will you speak before I am gone? will you prove already too late?" (11. 1321-1330). The poem has to end somewhere on the page; the poet Whitman can only do so much to encourage the reader to also speak, to participate. Hence at the very end of the poem Whitman can only promise to "stop somewhere waiting for you" (1. 1346); the poem may end but its meanings reverberate through the thoughts of the reader, if the reader will participate. The poem allows entrance whenever we are ready to begin our journey.

One can argue, therefore, that "Song of Myself," in its elaborate presentation of the character "Walt Whitman," serves as a kind of blueprint for the kind of poetry that Whitman will write, and for the kind of work that he will encourage others to write. In the short story "An Examination of the Work of Herbert Quain," Borges also presents a blueprint for a new kind of literature and a new kind of reader, though this "new" reader is certainly someone that Whitman would have appreciated and recognized. Within this story there is a narrator who is ostensibly Borges, but since he takes on the role of reader in examining Quain's work, and since Quain is actually Borges's own fictional creation, Borges has found an effective way to make his ideas seem no more his than ours; the reader can readily find his place in the "Borges" composite as just another reader and critic evaluating Quain's work.

The story is set up as an essay in which the narrator reviews the opus of the recently deceased Quain. One of the first things that we discover about Quain is that he believed in the active participation of the reader in his works; he believed, in fact, that the work could not really exist without an active reader. He therefore created works which actively sought reader participation.

Borges and his readers get the chance to critique a number of Quain's open-ended works, but it is in Quain's masterpiece, Statements, that the Whitmanic notion of supplying "half hints or less than half hints" is really brought to life. Quain wrote Statements, we are told, because he was fully convinced that the conventional reader was an endangered species. Quain argued that, "There is not a single person ... that is not a writer in potential or actuality."13 Quain admitted that not everyone would see himself or herself as a writer, or have the same initial facility for invention, but he insisted that the collaborative reader would soon be the rule, not the exception. His book Statements was thereby written for that new breed of readers.

Statements consists of eight beginnings of plots intentionally fouled up or cut short so that the readers could have the opportunity to salvage the plots in any way they might see fit. Quain thereby took an aggressive step towards making writers out of his active readers. Borges is thereby offering through Quain a way for the reader to be a true companion in the creative endeavor. Quain was satisfied to give the "hints," to set the "atmosphere," and then leave us to "pursue our own flights." 
Borges even goes one step further in "Quain" by claiming that he derived the plot for one of his own short stories, "The Circular Ruins," from one of the plots in Statements. Of course it is far from coincidence that that story is about a man who creates, by sheer will and artistry, a perfect "son," only to discover that he himself is also a mere figment of a prior creator. "The Circular Ruins" leaves us with the sense that "Borges" is a fiction, a fiction that we and Borges the writer create together whenever we read one of his stories. Hence the creation is not complete without our participation, even as "Whitman" is only real when we join Whitman in his poetry.

In "Quain" Borges introduces notions of a participating reader every bit as innovative and interesting as the notions Whitman created in "Song of Myself" and elsewhere. "Borges" the composite persona is not the largerthan-life hero that "Whitman" is, but he is every bit as much a potential composite of writer and reader. Both Whitman and Borges seek readers willing to work with "half hints and less than half hints," readers who feel equal to the role they must share in uncovering meaning in and bringing to fruition a work of art.

Borges clearly was fascinated by the distinction between Whitman the man and "Whitman" the character, a distinction that Whitman himself frequently sought to blur. Borges, however, has always been able to keep the two figures distinct; in fact he first made the distinction over fifty years ago, in his essay entitled "The Other Whitman." Borges's fascination with Whitman is mostly centered on Whitman the man, the poet, the literary theorist, and not on "Whitman" the superhero of the poems. Borges may be one of the few writers more interested in the artist than in his creation, "Walt Whitman," who seems to have influenced so many of Borges's contemporaries.

Whitman and Borges both have been accused of focusing too much on the self in their works. Perhaps these criticisms would diminish if critics would consider the possibility that the Whitman and Borges characters or personae that we meet in their writing are not merely representations of their creators, but also of every one of their readers, at least potentially. Both men bring the self into much of their work in order to invite a corresponding venture of self on the reader's part. Their work in that sense is other-centered, on the reader, whom both men see as essential to their work. In fact "Whitman" and "Borges," the primary figures of their respective creative endeavors, can only fully come to life when engaged by active readers who are willing and able to join with the authors to create the composite persona who encompasses them both. The trinity of writer, reader and persona that informs Whitman's work reemerges, though in a "quite different" form, in the fiction of Borges.

Northeast Missouri State University 


\section{NOTES}

1 José Santos Chocano, a Peruvian poet and one of the leaders of "modernismo," styled himself the Latin American Walt Whitman. See Phylis W. Rodríguez-Peralta, fosé Santos Chocano (New York: Twayne Publishing Company, 1970), p. 127. Pedro Mir's "Contracanto a Walt Whitman" is a long and detailed poem that presents a view of Whitman as the father of a movement toward equality and unity in the Hispanic world. See Mir's Viaje a la muchedumbre (Mexico City: Siglo Veintiuno Editores, 1972). For one fine and focused account of the influence of Whitman on the poetry of Darío, Martí, Paz and Neruda, see Doris Summer, "Adam and His Fallen Children, or Whitman from the Left, Right and Center," La Semana de Belles Artes, 176 (April 1981), 11-14.

2 Jorge Luis Borges, “An Autobiographical Essay," in El Aleph and Other Stories (New York: E. P. Dutton, 1970), p. 216.

3 Two of Borges's essays on Whitman are "Nota sobre Walt Whitman" and "El otro Whitman," both of which appear in Discusion, 1931. See also Borges's translation of selections from Leaves of Grass entitled Hojas de Hierba (Buenos Aires: Jiménez Editores, 1969).

4 In addition to the works cited in the above note, Borges has also frequently lectured about Whitman. One such lecture is documented in "Walt Whitman Man and Myth," Critical Inquiry, 4 (June 1975), 707-718.

5 Didier Tisdel Jaen, ed. and trans., Homage to Walt Whitman (University, Alabama: University of Alabama Press, 1964), p. xviii.

6 Borges made this statement during a lecture on Whitman at Michigan State University in 1976, the first in a series of lectures he presented there under the collective title of Preferences, which have been preserved on both video and audio tape by the University.

7 John Burroughs, for example, was aware that "Whitman always aimed to make his reader an active partner in his poetic enterprise." Burroughs also claimed that, "One source of his charm is that we each see some phase of ourselves in him." See John Burroughs, Whitman, $A$ Study (Boston: Houghton, Mifflin, 1896), pp. 143, 180.

8 See Eric Birdsall, “Translating the Hints: Whitman's Theory of Poetry," Walt Whitman Review, 26 (1980), 113-123. In this article Birdsall insists that Whitman's poetry calls for "an active and necessary partner." See also Thomas Rountree, "Whitman's Indirect Expression," $P M L A, 73$ (December 1955), 544-555. Rountree contends that "Song of Myself" reveals Whitman's method of "indirect expression," which virtually compels the reader into reciprocity in order to bring meaning to the poem.

9 In "A Backward Glance O'er Travel'd Roads," Whitman explicitly announces that "I seek less to state or display any theme or thought and more to bring you, reader, into the atmosphere of that theme or thought, there to pursue your own flight." Bucke's early biography of Whitman quotes the poet as saying, "I am sure my book necessitates that its reader transpose him or herself into that central position and become the actor, experiencer himself or herself of every page, every aspiration, every line." (Richard M. Bucke, Walt Whitman [New York: Johnson Reprint Company, 1970], p. 63.) In "Ventures on an Old Theme" Whitman states that "To have great poetry we need great audiences." In the 1876 preface to Leaves of Grass, Whitman avows that his job is to bring to the reader "Half hints and even less than half hints"; we are to supply the rest. And in Democratic Vistas Whitman really elaborates on this notion of the importance of a new kind of active reader for a new kind of literature:

In fact a new theory of literary composition for imaginative works of the first class and especially for highest poems is the sole course open to the States. Books are to be called for and supplied on the assumption that the process of reading is not a half sleep but in 
the highest sense a gymnast's struggle, that the reader is to do something himself or herself, must be on the alert, must himself or herself construct indeed the poem, argument ... the text itself furnishing the clue, the start or framework. Not the book needs so much to be the complete thing, but the reader of the book does.

10 Harold W. Blodgett and Sculley Bradley, eds., Leaves of Grass, Comprehensive Reader's Edition (New York: New York University Press, 1965), p. 137. All further quotations are from this edition.

11 Jorge Luis Borges, "El Zahir," in El Aleph (Buenos Aires: Emecé Editores, 1971), p. 105 (my translation).

12 Jorge Luis Borges, "The Garden of Forking Paths," as quoted in Ronald Christ, "Forking Narratives," in Simply a Man of Letters, ed. Carlos Cortinez (Orono: University of Maine Press, 1982), p. 76.

13 Jorge Luis Borges, "Examen de la obra de Herbert Quain," in Ficciones (Buenos Aires: Emecé Editories, 1971), p. 87 (my translation). 